\title{
Satellite-based Flood Modeling Using TRMM-based Rainfall Products
}

\author{
Amanda Harris ${ }^{1}$, Sayma Rahman ${ }^{2}$, Faisal Hossain ${ }^{1, *}$, Lance Yarborough ${ }^{3}$, Amvrossios C. \\ Bagtzoglou $^{2}$, Greg Easson ${ }^{3}$
}

1 Department of Civil and Environmental Engineering, Tennessee Technological University, Cookeville, TN 38505, USA

2 Department of Civil and Environmental Engineering, University of Connecticut, Storrs, CT 06269, USA

3 University of Mississippi Geoinformatics Center, Department of Geological Engineering, University of Mississippi, Oxford, MS, USA

* Author to whom correspondence should be addressed. E-mail: fhossain@tntech.edu

Received: 30 November 2007 / Accepted: 18 December 2007 / Published: 20 December 2007

\begin{abstract}
Increasingly available and a virtually uninterrupted supply of satellite-estimated rainfall data is gradually becoming a cost-effective source of input for flood prediction under a variety of circumstances. However, most real-time and quasi-global satellite rainfall products are currently available at spatial scales ranging from $0.25^{\circ}$ to $0.50^{\circ}$ and hence, are considered somewhat coarse for dynamic hydrologic modeling of basin-scale flood events. This study assesses the question: what are the hydrologic implications of uncertainty of satellite rainfall data at the coarse scale? We investigated this question on the $970 \mathrm{~km}^{2}$ Upper Cumberland river basin of Kentucky. The satellite rainfall product assessed was NASA's Tropical Rainfall Measuring Mission (TRMM) Multi-satellite Precipitation Analysis (TMPA) product called 3B41RT that is available in pseudo real time with a latency of 6-10 hours. We observed that bias adjustment of satellite rainfall data can improve application in flood prediction to some extent with the trade-off of more false alarms in peak flow. However, a more rational and regime-based adjustment procedure needs to be identified before the use of satellite data can be institutionalized among flood modelers.
\end{abstract}


Keywords: Satellite rainfall, statistical downscaling, floods, uncertainty.

\section{Introduction}

Although there are several sources of uncertainty that complicate our understanding of flood prediction accuracy, the principal source of uncertainty is, undoubtedly, rainfall (Kavetski et al., 2006; Krzyzstofowicz, 1999, 2001). Syed et al. (2004) has corroborated this further by demonstrating that $70 \%-80 \%$ of the variability observed in the terrestrial hydrologic cycle is, in fact, attributed to rainfall. Considering that floods impact more people globally than any other type of natural disaster (World Disasters Report, 2003), it is critical to monitor rainfall effectively for mitigation purposes. Experience indicates that the most effective way to reduce the property damage and life loss is the development of flood early warning systems (Negri et al., 2004).

However, given the systematic and global decline of in situ networks for hydrologic measurements (Stokstad, 1999; Shikhlomanov et al., 2002), hydrologists today are beginning to realize that rainfall data from the vantage of space has the potential to become a cost-effective source of input for flood prediction. There are some particularly unique attributes of satellite rainfall data that must be recognized by end-users for the prediction of flood events. These are: i) easy availability on a global basis from the internet; the spatio-temporal frequency of sampling is expected to increase in future with the advent of Global Precipitation Measurement (GPM) mission (see http://gpm.gsfc.nasa.gov and Smith et al., 2007); ii) virtually uninterrupted supply of rainfall data for maintaining functionality of operational land-based systems during catastrophic situations that can temporarily shut down ground networks (e.g., overland effects of hurricanes/earthquakes/tsunamis); iii) the availability of basin-wide rainfall data in transboundary river basins where riparian nations lack treaties for real-time rainfall data sharing across political boundaries (Hossain et al., 2007; Hossain and Katiyar, 2006).

The recognition of the global importance of satellite derived rainfall has led to the development of an increasing number of satellite-based rainfall products that are now available to meet the needs of various users (for a summary of currently available products refer to Ebert et al., 2007). However, most of these (real-time) products are available at spatial scales that may be considered somewhat coarse for hydrologic modeling of flood events. For example, satellite algorithms like Global Precipitation Climatology Project (GPCP; Huffman et al., 2001), PERSIANN (Sorooshian et al., 2000), CMORPH (Joyce et al., 2004) and Tropical Rainfall Measuring Mission (TRMM) Multisatellite Precipitation Analysis (TMPA; Huffman et al., 2007) are currently available at scales of $0.25^{\circ}$ or larger. In this study, we therefore address the question: what are the hydrologic implications of uncertainty of satellite rainfall data at the native (coarse) scale? The motivation is to understand the current level of predictability that can be achieved for flood prediction using global satellite rainfall datasets. 


\section{Study Area and Data}

Our study area is a $970 \mathrm{~km}^{2}$ basin of the Upper Cumberland River in southeastern Kentucky (KY) bordering with Virginia and Tennessee (Figure 1). The area is primarily mountainous and

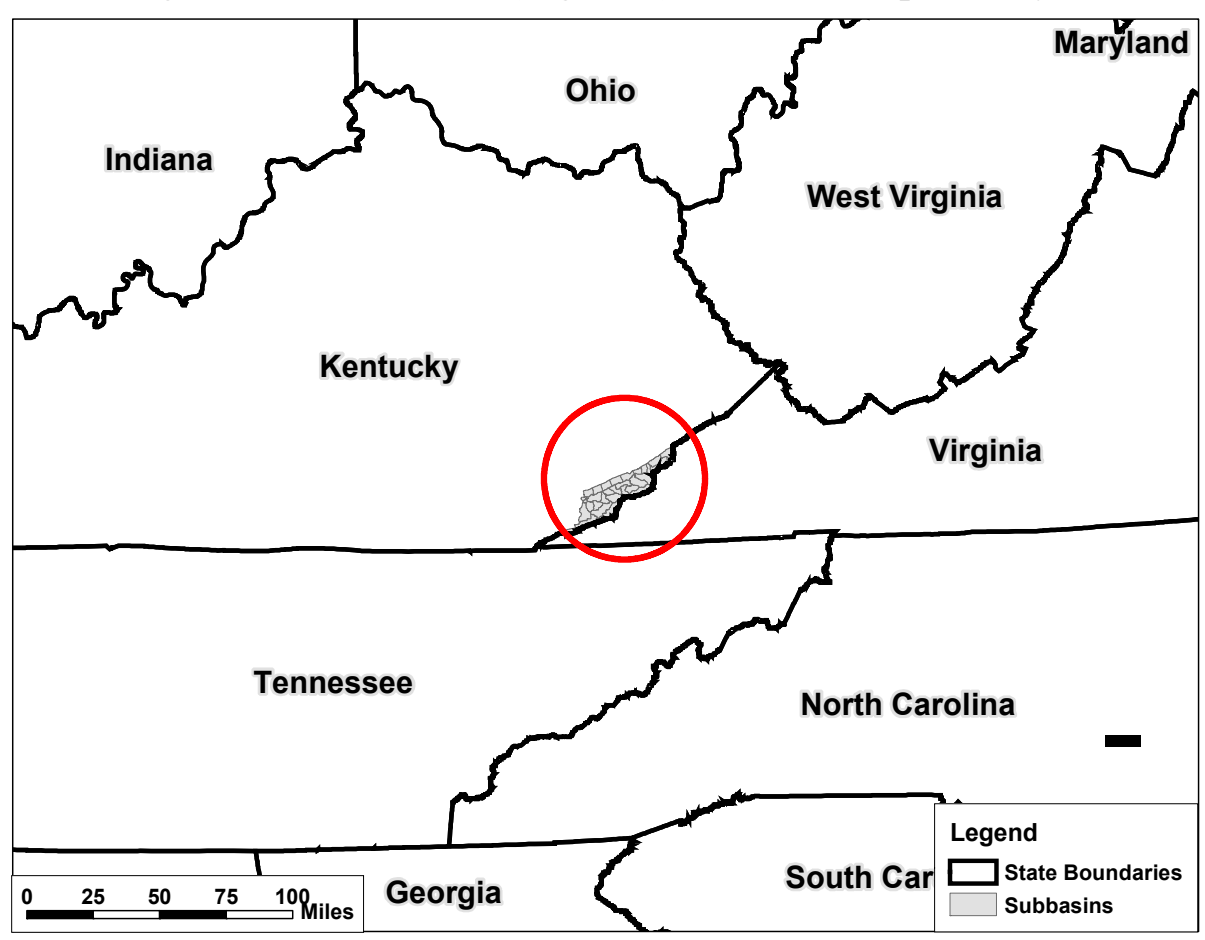

Figure 1. Upper Cumberland basin location.

forested, and it lies in the Eastern Coal Field physiographic region. The underlying rock formations are primarily sandstone, shale, and siltstone. The percentage distribution of major land use types is forest land $(80.13 \%)$, urban $(8.20 \%)$, cropland and pasture $(11.15 \%)$, and lakes and reservoirs combined $(0.52 \%)$. The outlet of the basin is in the town of Loyall. Three high-gradient mountain streams, Martin's Fork, Poor Fork, and Clover Fork, join to form the Cumberland River near Harlan (Figure 2). The population of the four major towns totals approximately 6500. The Upper Cumberland region has been subject to periodic disastrous flooding. In April 1977, record rainfall caused severe flooding and damage to Harlan County. Other large and disastrous floods occurred in the years of 1946, 1957, 1972, and 2002.

The storm event for this study took place on March 16-20, 2002, with the majority of the rainfall occurring on March $17^{\text {th }}$ and $18^{\text {th }}$. The total storm rainfall volume was 6.12 inches over the basin. The observed streamflow was taken at the outlet of the basin in Loyall, Kentucky at the United States Geological Survey streamflow gage \#03401000, which was operated in cooperation with the U.S. Army Corps of Engineers (USACE). The peak flow for the storm was approximately 29,600 cfs (Figure 3).

The reference rainfall dataset for calibrating hydrologic models comprised the WSR-88D Stage III data that were calibrated to the gages in and around the basin (Fulton et al., 1998). Using the gageadjusted WSR Stage-III radar rainfall data as reference for ground validation (GV) data, it was possible derive very accurate stream flow simulations for various model configurations (see Figure 4). Table 1 also summarizes the various error statistics in hydrograph simulation obtained with WSR-88D 
rainfall estimates. Due to the very negligible difference observed between WSR-88D-simulated and observed stream flow (Table 1 and Figure 2), all subsequent assessment of satellite derived stream flow simulation was therefore performed with respect to the observed stream flow hydrograph.

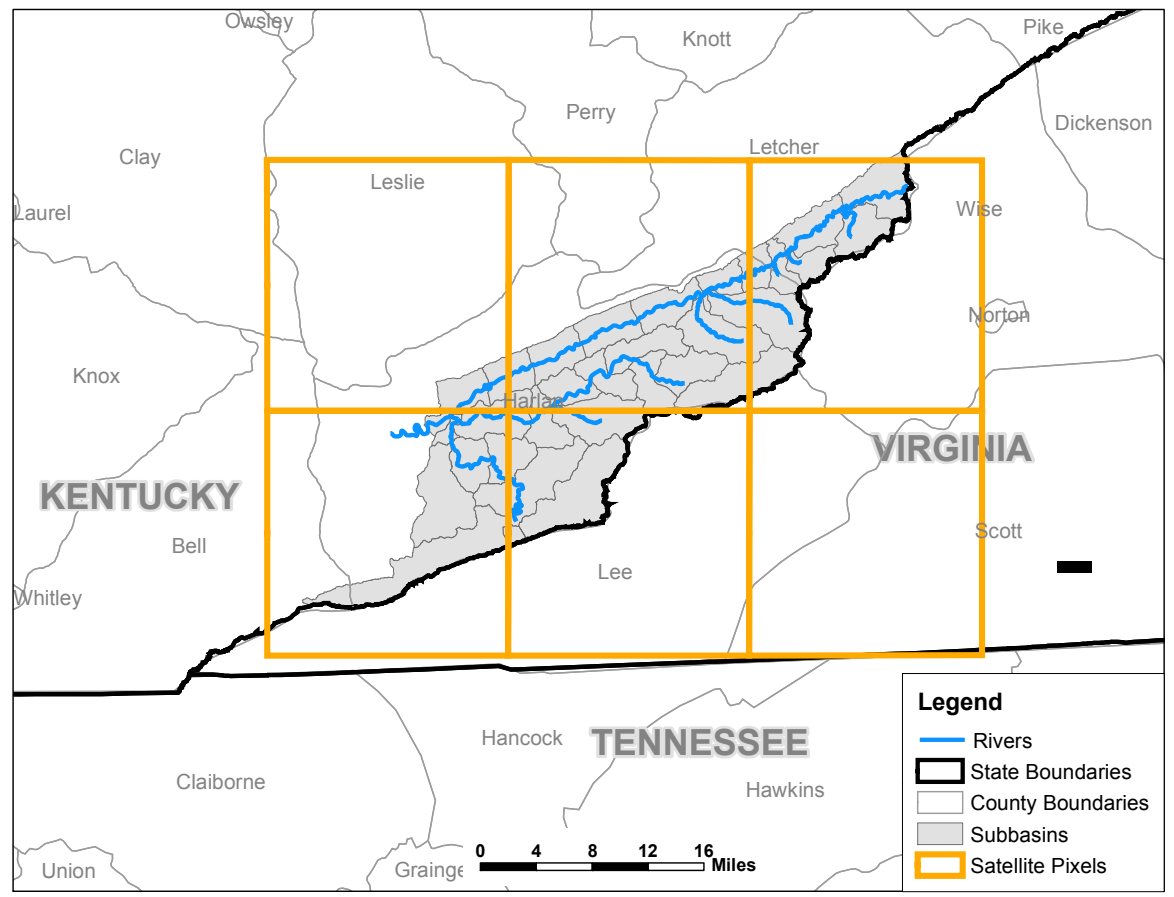

Figure 2. River network of the Upper Cumberland basin. Gridboxes in yellow represent the location of 3B41RT satellite rainfall pixels over the basin.

For satellite rainfall data, we use the TRMM Multi-satellite Precipitation Analysis (TMPA) product. The TMPA provides a calibration-based sequential scheme for combining rainfall estimates from various satellites, at fine scales $\left(0.25^{\circ} \mathrm{x} 0.25^{\circ}\right.$ and 3-hourly) (Huffman et al., 2007). It is available both after and in real time, based on calibration by the TRMM Combined Instrument and TRMM Microwave Imager precipitation products, respectively. In this study we assessed the IR-based product known as 3B41RT $\left(0.25^{\circ}\right.$ and hourly). The subscript 'RT' to each product name refers to real time, which in reality refers to a pseudo real time where data is available to the use via the internet with a 8-

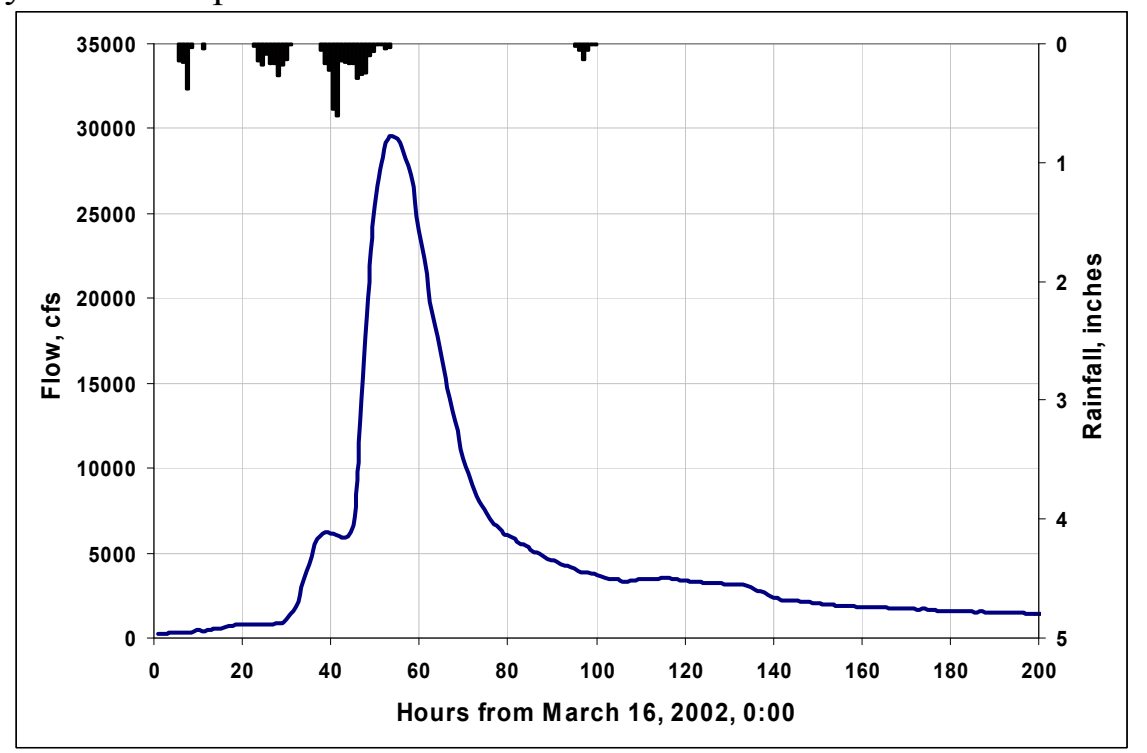

Figure 3. Rainfall and runoff for the March 2002 storm event. 
16 hour latency for the end user. Because our analysis was intended for assessing the reliability of satellite products for now casting applications (such as flood forecasting and sequential data assimilation), we have chosen to use this 'RT' product. The 3B41RT data set covers the latitude band $50^{\circ} \mathrm{N}-\mathrm{S}$ for the period 2002 to the present.

\section{Hydrologic Model Configurations}

We selected the Hydrologic Engineering Center's (HEC) Hydrologic Modeling System (HMS) to perform our assessment on three hydrologic model configurations. We also used the topographic index based model called TOPMODEL, first developed by Beven and Kirkby (1979), as our fourth model configuration. The use of multiple (four) conceptual model configurations thereby helped us to remove any potential bias of our findings for a particular model choice. USACE's on-going work involving HEC-HMS over the Upper Cumberland basin allowed us access to various calibration and input databases that were found to be already quality-controlled. Each hydrologic model configuration concerned a particular infiltration scheme conceptualization to calculate excess rainfall (i.e., runoff generation) leading to surface runoff. Other components of the model such as base flow, river routing,

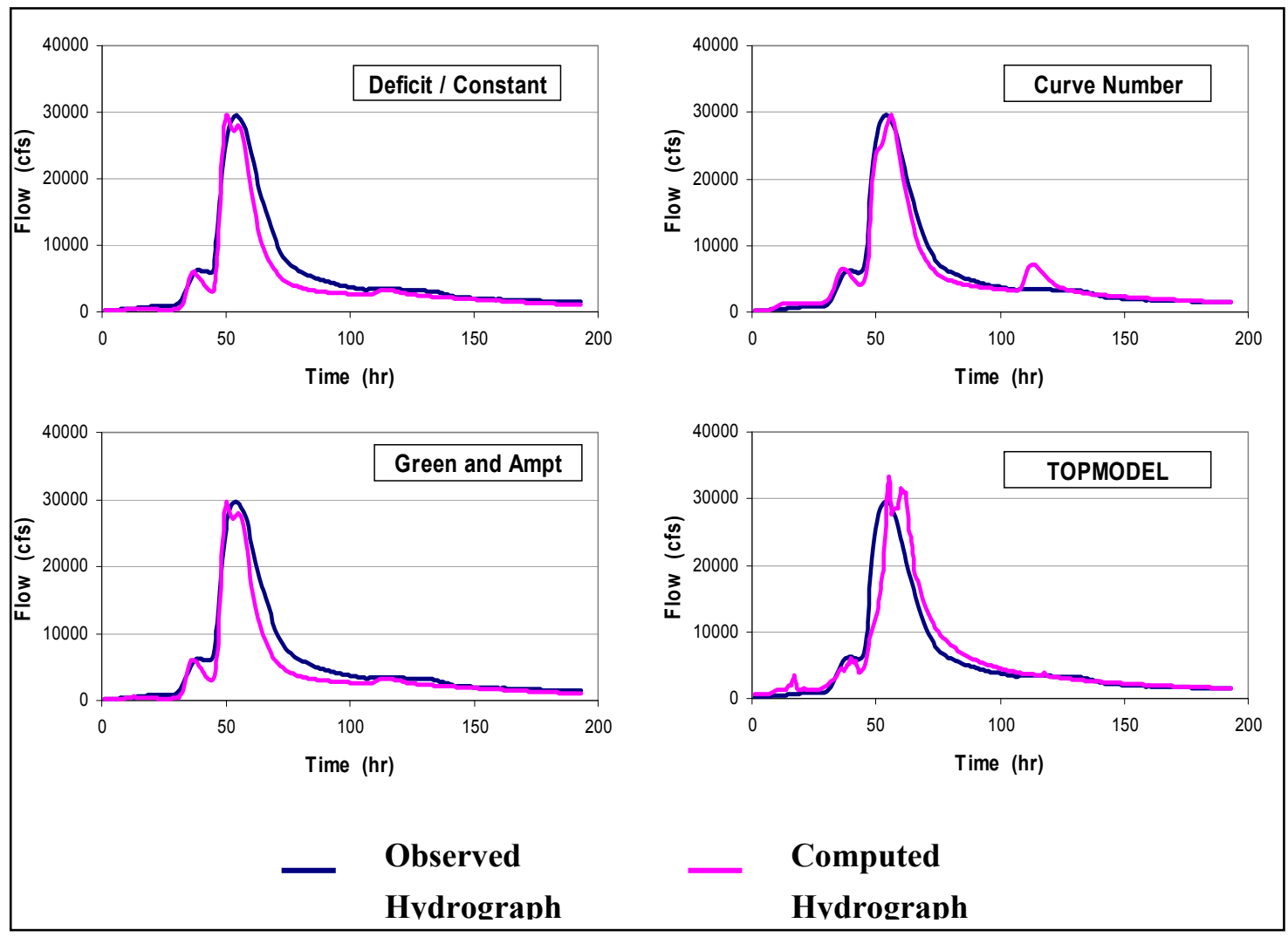

Figure 4. Observed versus simulated stream flow for four hydrologic model configurations in the UC river basin (taken from Harris, 2007). Note: Other than TOPMODEL, all other configurations shown above can be set up in HEC-HMS.

evapo-transpiration were kept constant. The Muskingum-Cunge routing (Barry and Bajracharya, 1995) and ModClark transformation (Kull and Feldman, 1998) method was used across all model types in 
HEC-HMS. Required parameters for surface runoff routing were length, energy slope, Manning's n roughness coefficients, and station-elevation data. The reader is referred to the HEC-HMS Technical Reference Manual, March 2000 for more details on these methods. The three infiltration schemes considered were: i) Deficit/Constant loss method; ii) Green-Ampt Infiltration; iii) NRCS Curve

Table 1. Runoff error statistics for calibrated models based on WSR-88D Stage-III radar rainfall data. Error is defined as the difference in observed and modeled value and expressed as a \% relative to the observed value.

\begin{tabular}{|c|c|c|c|}
\hline & \multicolumn{3}{|c|}{ Peak Flow } \\
\hline $\begin{array}{c}\text { Hydrologic } \\
\text { Model } \\
\end{array}$ & $\begin{array}{c}\text { Observed } \\
\text { (cfs) }\end{array}$ & $\begin{array}{c}\text { Computed } \\
\text { (cfs) }\end{array}$ & $\begin{array}{c}\text { Error } \\
(\%)\end{array}$ \\
\hline $\mathrm{D} / \mathrm{C}$ & 29600 & 29584 & 0.05 \\
\hline Curve Number & 29600 & 29574 & 0.09 \\
\hline Green and Ampt & 29600 & 29524 & 0.26 \\
\hline \multirow{2}{*}{ TOPMODEL } & 29600 & 33258 & 12.4 \\
\hline & \multicolumn{3}{|c|}{ Total Runoff Volume } \\
\hline $\begin{array}{c}\text { Hydrologic } \\
\text { Model } \\
\end{array}$ & $\begin{array}{c}\text { Observed } \\
\text { (in) }\end{array}$ & $\begin{array}{c}\text { Computed } \\
\text { (in) } \\
\end{array}$ & $\begin{array}{c}\text { Error } \\
(\%)\end{array}$ \\
\hline $\mathrm{D} / \mathrm{C}$ & 4.43 & 3.49 & 21.2 \\
\hline Curve Number & 4.43 & 4.24 & 4.3 \\
\hline Green and Ampt & 4.43 & 4.22 & 4.7 \\
\hline \multirow[t]{2}{*}{ TOPMODEL } & 4.43 & 4.58 & 3.4 \\
\hline & \multicolumn{3}{|c|}{ Time to Peak } \\
\hline $\begin{array}{c}\text { Hydrologic } \\
\text { Model }\end{array}$ & $\begin{array}{c}\text { Observed } \\
\text { (hr) }\end{array}$ & $\begin{array}{c}\text { Computed } \\
(\mathbf{h r})\end{array}$ & $\begin{array}{c}\text { Error } \\
(\%)\end{array}$ \\
\hline $\mathrm{D} / \mathrm{C}$ & 53 & 49 & 7.6 \\
\hline Curve Number & 53 & 55 & 3.8 \\
\hline Green and Ampt & 53 & 49 & 7.6 \\
\hline TOPMODEL & 53 & 55 & 3.8 \\
\hline
\end{tabular}

Number Method. For TOPMODEL, the topographic index was derived from a 10-meter resolution Digital Elevation Model (DEM) for the Upper Cumberland watershed using a multiple flow direction algorithm by Quinn et al. (1995). For the case of unsaturated zone drainage, a simple gravitycontrolled approach is adopted in the TOPMODEL version used in this study. All model configurations were calibrated using WSR-88D radar rainfall data. The watershed was discretized into 31 smaller sub-basins (Figure 2) to account for the hydrologic variability of the rainfall-runoff process within. Although complete details of the entire calibration process are not shown here due to the limitations on space, they may be accessed from the work of Harris (2007; unpublished thesis, available upon request). Figure 2 also shows the location of the $0.25^{\circ}$ satellite gridboxes of the IR3B41RT product over the watershed. 


\section{Implications of Satellite Rainfall Uncertainty on Flood Prediction}

Generally, when applying actual satellite rainfall data to the models with parameters calibrated to WSR-88D radar rainfall data, our preliminary observation was that the 3B41RT algorithm suffered from systematic underestimation (negative bias) for the March 2002 storm event. This resulted in an underestimated flood hydrograph (Figure 5). Table 2 shows the error statistics for peak flow, runoff volume and time to peak. Except for the time to peak, very high percentages of errors $(>50 \%)$ are observed for all three model configurations. Generally, such systematic underestimation of rainfall for IR-based algorithm is not uncommon (Huffman et al., 2007) given that IR sensors are capable of sensing only the cloud top radiation as a proxy for surface rainfall. A particular difficulty of IR algorithms is to detect rain during winter from shallow and warm clouds. Previous studies by Hossain and Anagnostou (2004) and Borga (2002) also confirm that a systematic effect in rainfall estimation can be propagated in a similarly systematic manner in streamflow simulation (as observed from Figure 5). In a recent assessment of global satellite rainfall products, Ebert et al. (2007) also reported that IR algorithms tend to underestimate rainfall by $50 \%$ in eastern US during summer.

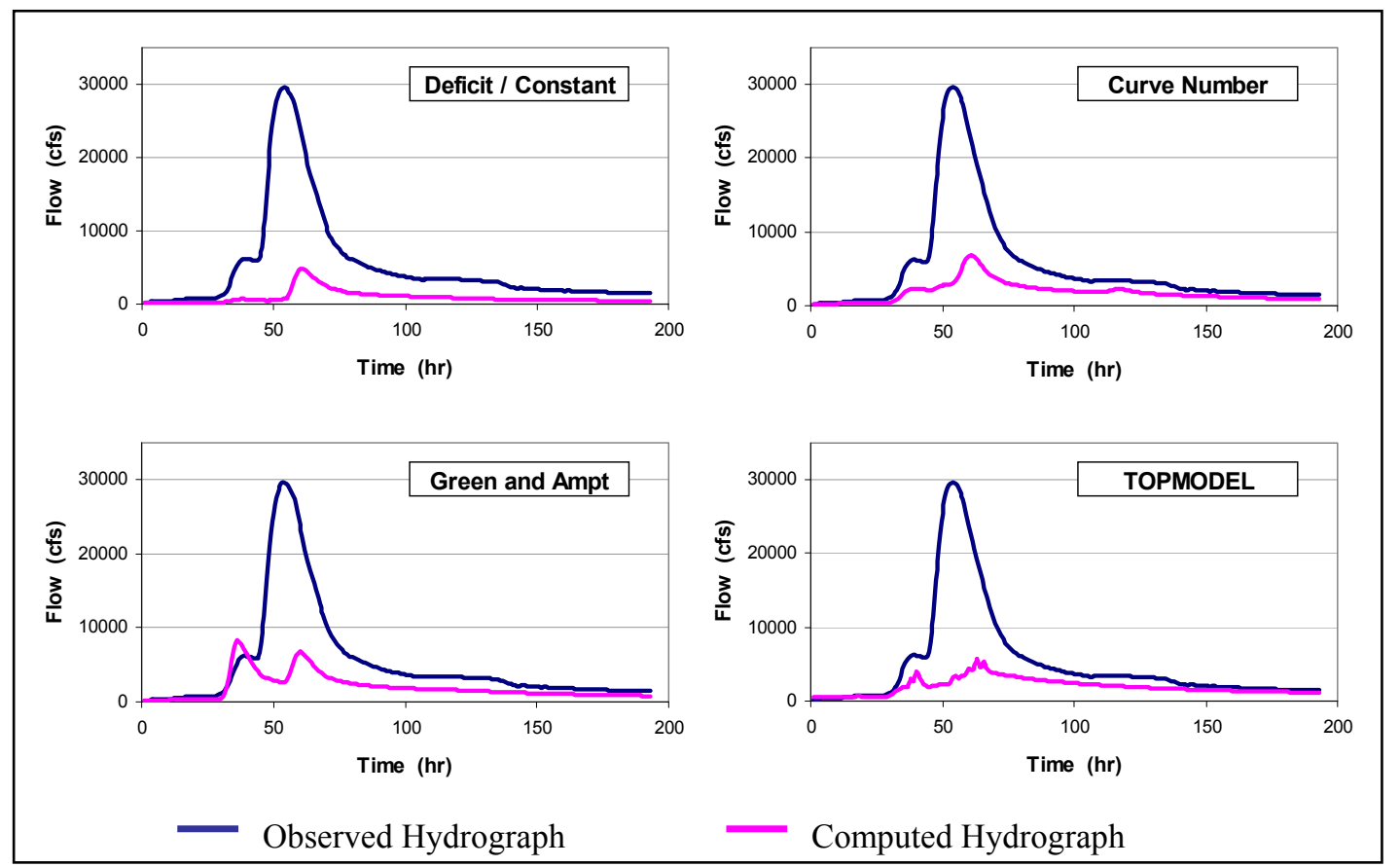

Figure 5. Computed vs. Observed Hydrographs using actual satellite rainfall data (unadjusted) at the native scale of $0.25^{\circ}$.

As a remedial step, the satellite data set was adjusted upward by a factor of 2.34 , and the simulations were repeated. The bias of 2.34 was derived from the WSR and satellite cumulative rainfall hyetographs shown in Figure 6 by dividing the WSR rainfall volume by 3B41RT rainfall volume. With the bias adjustments, tangible improvement in the reduction of streamflow uncertainty was observed (Table 3). However, this simple bias adjustment also resulted in the simulation of a false stream flow peak prior to the true flood peak time (Figure 7). As a community, we now need to 
question the practicality and utility of simple bias adjustment of satellite rainfall for flood prediction. As has been reported in the past (see Hossain and Anagnostou, 2004), bias adjustment is not a complete remedy on its own as certain residual error in the form of false detected rain/no-rain remains unaccounted for. We have clearly seen herein that while the runoff volume simulation accuracy may increase with bias adjustment, the tendency to produce false alarms of flood peaks also increases.

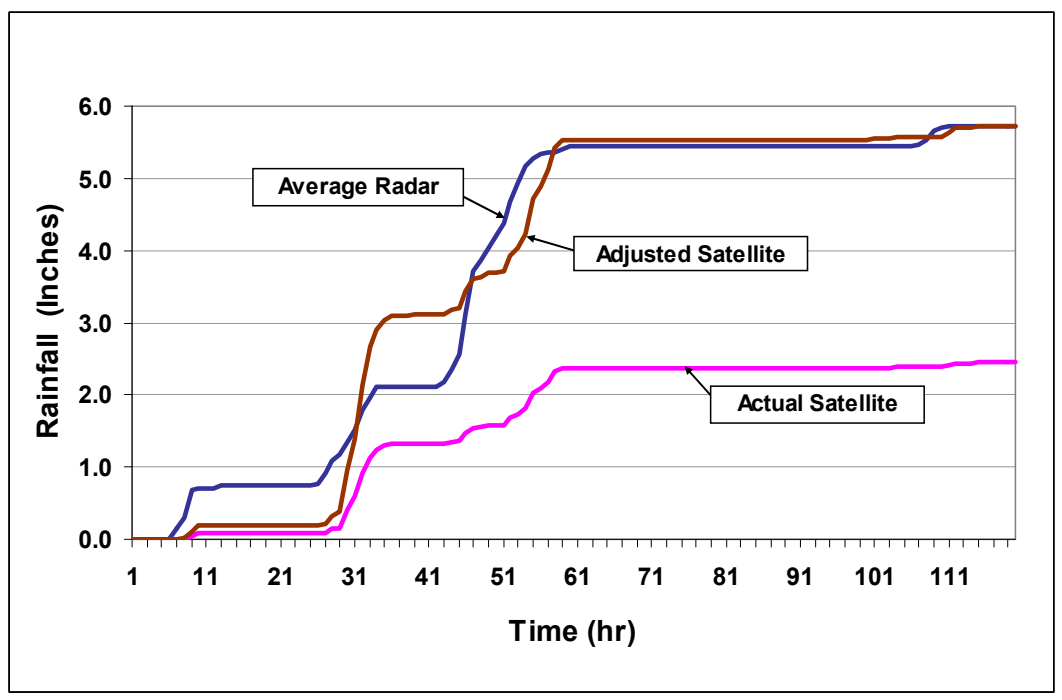

Figure 6. Cumulative satellite rainfall hyetographs for deriving bias adjustment.

Table 2. Streamflow error statistics using actual (unadjusted) satellite rainfall data.

\begin{tabular}{|c|c|c|c|}
\hline & \multicolumn{3}{|c|}{ Peak Flow } \\
\hline Loss Method & Observed (cfs) & Computed (cfs) & Error (\%) \\
\hline $\mathrm{D} / \mathrm{C}$ & 29600 & 4823 & 83.7 \\
\hline Curve Number & 29600 & 6848 & 76.9 \\
\hline $\begin{array}{c}\text { Green and } \\
\text { Ampt }\end{array}$ & 29600 & 8360 & 71.8 \\
\hline & \multicolumn{3}{|c|}{ Total Volume } \\
\hline Loss Method & Observed (in) & Computed (in) & Error (\%) \\
\hline $\mathrm{D} / \mathrm{C}$ & 4.43 & 0.85 & 80.8 \\
\hline Curve Number & 4.43 & 1.63 & 63.2 \\
\hline $\begin{array}{c}\text { Green and } \\
\text { Ampt }\end{array}$ & 4.43 & 1.75 & 60.5 \\
\hline & \multicolumn{3}{|c|}{ Time to Peak } \\
\hline Loss Method & Observed (hr) & Computed (hr) & Error (\%) \\
\hline $\mathrm{D} / \mathrm{C}$ & 53 & 60 & 13.2 \\
\hline Curve Number & 53 & 60 & 13.2 \\
\hline $\begin{array}{c}\text { Green and } \\
\text { Ampt }\end{array}$ & 53 & 35 & 34.0 \\
\hline
\end{tabular}


Table 3. Streamflow error statistics using bias-adjusted satellite rainfall data.

\begin{tabular}{|c|c|c|c|}
\hline & \multicolumn{3}{|c|}{ Peak Flow } \\
\hline Loss Method & Observed (cfs) & Computed (cfs) & Error $(\%)$ \\
\hline $\mathrm{D} / \mathrm{C}$ & 29600 & 25348 & 14.4 \\
\hline Curve Number & 29600 & 28580 & 3.4 \\
\hline \multirow[t]{2}{*}{$\begin{array}{c}\text { Green and } \\
\text { Ampt }\end{array}$} & 29600 & 38406 & 29.8 \\
\hline & \multicolumn{3}{|c|}{ Total Volume } \\
\hline Loss Method & Observed (in) & Computed (in) & Error (\%) \\
\hline $\mathrm{D} / \mathrm{C}$ & 4.43 & 3.63 & 18.1 \\
\hline Curve Number & 4.43 & 4.27 & 3.6 \\
\hline \multirow[t]{2}{*}{$\begin{array}{c}\text { Green and } \\
\text { Ampt }\end{array}$} & 4.43 & 4.73 & 6.8 \\
\hline & \multicolumn{3}{|c|}{ Time to Peak } \\
\hline Loss Method & Observed (hr) & Computed (hr) & Error (\%) \\
\hline $\mathrm{D} / \mathrm{C}$ & 53 & 59 & 11.3 \\
\hline Curve Number & 53 & 60 & 13.2 \\
\hline $\begin{array}{c}\text { Green and } \\
\text { Ampt }\end{array}$ & 53 & 35 & 34.0 \\
\hline
\end{tabular}

Figure 5 also represents a rather humbling picture of current reliability of satellite data products from the TMPA algorithm of 3B41RT. In its original form, these products were developed by data producers to facilitate large-scale climatologic and meteorological inquiries (such as understanding the global energy and water budget). Hence, we should not generalize the negative bias of 3B41 product. This TMPA product has also been observed to have insignificant (positive) bias in many regimes/seasons (see Ebert et al., 2007) where the flood prediction accuracy would potentially be more accurate (different) than what is reported herein. The more critical question that we should ask ourselves is how can we generalize the procedure for error adjustment of satellite data as a function of regime and season? Another follow-up question is what should be the nature of this error adjustment (is simple bias adjustment adequate)? As reported by Hossain and Anagnostou (2006) multidimensional error adjustment can significantly improve cumulative rainfall observation of satellite. However, the efficacy of such a technique is yet to be tested on terrestrial hydrologic modeling. Nevertheless, given the work already accomplished on global classification of precipitation systems and finding similarities in regions with benchmark (validation) rainfall data (Petersen and Rutledge, 2002), we are hopeful that satellite rainfall data adjustment will eventually evolve to something useful for ungauged regions. 

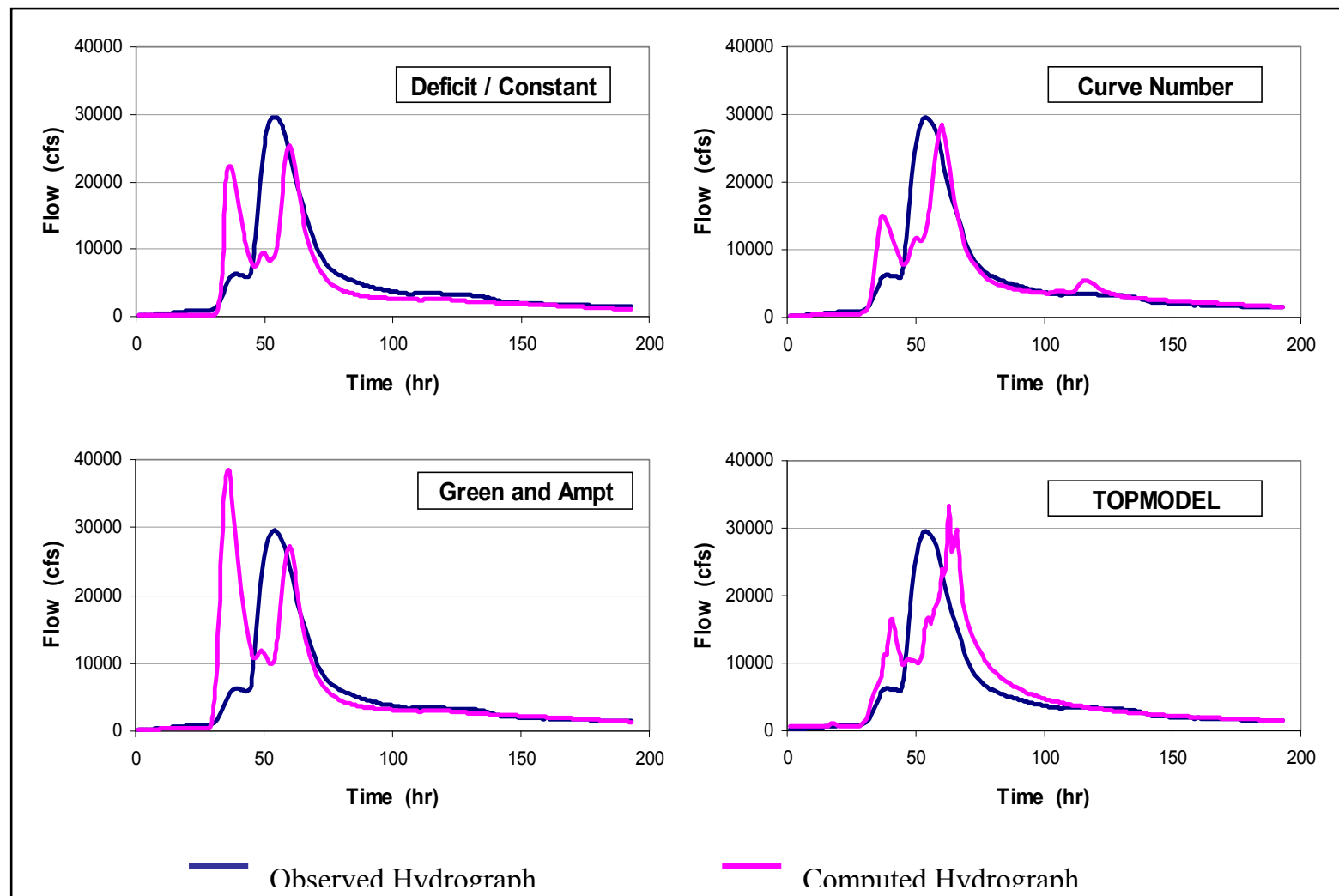

Figure 7. Computed vs. Observed Hydrographs using actual satellite rainfall data (adjusted) at the native scale of $0.25^{\circ}$.

\section{Conclusion}

Our findings indicate that the current level of uncertainty in satellite rainfall warrants caution before institutionalizing its use in operational flood forecasting systems at the basin scale. Also, we need to find ways to generalize error adjustment schemes for satellite data as a function of regime, season and location. Although it is not clear at this stage how complex this adjustment should be, it is obvious that the adjustment needs to go beyond simple bias adjustment to minimize the model's propensity to produce false peaks in flow or to miss true peaks. A more comprehensive investigation involving a greater number of watersheds as a function of region and season now needs to be carried out in order to generalize rules for hydrologic application of satellite rainfall in anticipation of GPM.

\section{Acknowledgements}

The authors acknowledge the help received from the USACE Nashville District with data and model set-up. The first author (Amanda Harris) was supported by the Department of Civil and Environmental Engineering, Tennessee Technological University. The second author (Sayma Rahman) was supported by the Selected Professions Fellowship from the American Association of University Women (AAUW). Supplemental support from the Center for Environmental Sciences and Engineering at the University of Connecticut was also provided to the second author. 


\section{References and Notes}

1. Barry, D.A.; Bajracharya, K.. On the Muskingum-Cunge Flood Routing Method, Environmental International 1995 21(5), 485-490. (doi: 10.1016/0160-4120(95)00046-N).

2. Beven, K.J.; Kirkby, M.J. A physically-based variable contributing area model of basin hydrology. Hydrological Sciences Bulletin 1979 24(1), 43-69.

3. Borga, M. Accuracy of radar rainfall estimates for stream-flow simulation. Journal of Hydrology 2002, 267, 26-39.

4. Ebert, E; Janowiak, J.E; Kidd, C. Comparison of near real-time precipitation estimates from satellite observations and numerical models, Bulletin of American Meteorological Society 2007 88, 47-64.

5. Fulton, R.A.; Breidenbach, J.P.; Seo, D.J.; Miller, D.A.; O’Bannon, T. The WSR-88D Rainfall Algorithm. Weather and Forecasting 1998, 13(2), 377-395.

6. Harris, A. Investigating the optimal configuration of conceptual hydrologic models for satellite based flood prediction. M.S. Thesis (unpublished), 2007, Department of Civil and Environmental Engineering, Tennessee Technological University.

7. Hossain, F.; Katiyar, N.; Wolf, A.; Hong, Y. The Emerging role of Satellite Rainfall Data in Improving the Hydro-political Situation of Flood Monitoring in the Under-developed Regions of the World, Natural Hazards 2007, 43, 199-210. (doi 10.1007/s11069-006-9094-x).

8. Hossain, F; Anagnostou. E.N. Assessment of a multi-dimensional satellite rainfall error model for ensemble generation of satellite rainfall data, IEEE Geosciences and Remote Sensing Letters 2006, 3(3), 419-423 (doi 10.1109/LGRS.2006.873686).

9. Hossain, F; and Katiyar, N. Improving Flood Forecasting in International River Basins EOS (AGU) 2006, 87(5), 49-50.

10. Hossain, F.; Anagnostou, E.N. Assessment of current passive microwave and infrared based satellite rainfall remote sensing for flood prediction. Journal of Geophysical ResearchAtmosphere 2004, 109, D07102.

11. Huffman, G.J.; Adler, R.F.; Morrissey, M.; Bolvin, D.T.; Curtis, S.; Joyce, R.; McGavock, B.; Susskind, J. Global precipitation at one-degree daily resolution from multi-satellite observations. Journal of Hydrometeorology 2001, 2, 36-50.

12. Huffman, G.J.; Adler, R.F.; Bolvin, D.T.; Gu, G.; Nelkin, E.J.; Bowman, K.P.; Hong, Y.; Stocker, E.F.; Wolff, D.B. The TRMM Multi-satellite Precipitation Analysis: Quasi-Global, Multi-Year, Combined-Sensor Precipitation Estimates at Fine Scale. Journal of Hydrometeorology 2007, 8, $38-55$.

13. Joyce, R.L.; Janowiak, J.E.; Arkin, P.A.; Xie, P. CMORPH: A method that produces global precipitation estimates from passive microwave and infrared data at high spatial and temporal resolution. Journal of Hydrometeorology 2004, 5, 487-503.

14. Kavetski, D.; Kuczera, G.; Franks, S.W. Bayesian analysis of input uncertainty in hydrological modeling: 2 Application. Water Resources Research 2006, 42, (W03408) (doi:10.1029/2005WR004376). 
15. Krzyzstofowicz, R. Bayesian theory of probabilistic forecasting via deterministic hydrological model. Water Resources Research 1999, 35(9), 2739-2750.

16. Krzyzstofowicz, R. The case for probabilistic forecasting in hydrology. Journal of Hydrology 2001, 249, 2-9.

17. Kull, D.W.; Feldman, A.D. Evolution of Clark's Unit Graph Method to Spatially Distributed Runoff. Journal of Hydrologic Engineering 1998, 3(1), 9-19 (doi: 10.1061/(ASCE)1084-0699).

18. Negri, A; Burkardt, N.; Golden, J.H.; Halverson, J.B.; Huffman, G.J.; Larsen, M.C.; Mcginley, J.A.; Updike, R.G.; Verdin, J.P; Wieczorek, J.F. The Hurricane-Flood-Landslide Continuum, Bulletin of American Meteorological Society 2004 (doi:10.1175/BAMS-86-9-1241).

19. Petersen, W.A.; Rutledge, S.A. Regional variability in tropical convection: observations from TRMM. Journal of Climate 2002, 14, 3566-3586.

20. Quinn P.F.; Beven, K.J.; Lamb, R. The $\ln (\mathrm{a} / \operatorname{tanb})$ index: how to calculate it and how to use it in the TOPMODEL framework. Hydrological Processes 1995, 9, $161-182$.

21. Shiklomanov, A.I.; Lammers, R.B.; Vörösmarty, C.J. Widespread decline in hydrological monitoring threatens pan-arctic research. EOS Transactions 2002, 83(2), 16-17.

22. Smith E.; Asrar, G.; Furuhama, Y.; Ginati, A.; Kummerow, C.; Levizzani, V.; Mugnai, A.; Nakamura, K.; Adler, R.; Casse, V.; Cleave, M.; Debois, M.; Durning, J.; Entin, J.; Houser, P.; Iguchi, T.; Kakar, R.; Kaye, J.; Kojima, M.; Lettenmaier, D.P.; Luther, M.; Mehta, A.; Morel, P.; Nakazawa, T.; Neeck, S.; Okamoto, K.; Oki, R.; Raju, G.; Shepherd, M.; Stocker, E.; Testud, J.; Wood, E.F. The international global precipitation measurement (GPM) program and mission: An overview. In, Measuring Precipitation from Space: EURAINSAT and the Future, (Eds) V. Levizzani and F.J. Turk, Kluwer Academic Publishers, 2006 (In Press).

23. Sorooshian, S.; Hsu, K.L.; Gao, X.; Gupta, H.V.; Imam, B., Braithwaite, D. Evaluation of PERSIANN system satellite-based estimates of tropical rainfall. Bulletin of American Meteorological Society 2000, 81, 2035-2046.

24. Stokstad, E. Scarcity of rain, stream gages threatens forecasts. Science 1999, 285, 1199.

25. Syed, T.H.; Lakshmi, V.; Paleologos, E.; Lohmann, D.; Mitchell, K.; Famiglietti, J. Analysis of process controls in land surface hydrological cycle over the continental United States. Journal of Geophysical Research 2004, 109(D22105), (doi: 10.1029/2004JD004640).

26. World Disasters Report. International Federation of Red Cross and Red Crescent Societies, 2003, 239.

(C) 2007 by MDPI (http://www.mdpi.org). Reproduction is permitted for noncommercial purposes. 